Pawłowski, J. (2018). Individual investors on the financial market in Poland. Copernican Journal of Finance \& Accounting, 7(1), 51-66. http://dx.doi.org/10.12775/CJFA.2018.004

\author{
Jaroskaw Pawkowski* \\ Nicolaus Copernicus University in Toruń
}

\title{
INDIVIDUAL INVESTORS ON THE FINANCIAL \\ MARKET IN POLAND
}

Keywords: investments, financial instruments, individual investors.

\section{J E L Classification: G11.}

Abstract: The influence of individual investors on the functioning of the financial market makes them a very important group of its participants. The observed growth of the financial market in Poland generates more investment opportunities. Considering the changes that occur in this field, the issue of financial investments made by individual investors in Poland is quite interesting and important.

The research objective of the paper is the analysis of investments of individual investors in Poland in terms of their subjects.

The research method applied: descriptive, comparative, review of subject literature and analysis of third party research results which were carried out by the Individual Investors Association in Poland and Narodowy Bank Polski. Moreover, analysis of selected findings of author's individual survey amongst private investors were the main part of this article.

The conducted analysis has allowed to formulate a number of conclusions. One of the major conclusions indicated that stocks were the main subject of investments made by individual investors in the recent years. Furthermore, increased importance of bonds has been determined, but the interest in bank deposits was lower. Nevertheless, bank deposits have remained the main financial assets of households in Poland.

Date of submission: February 15, 2018; date of acceptance: May 11, 2018.

* Contact information: jpawlowski@umk.pl, Department of Finance Management, Faculty of Economic Sciences and Management, Nicolaus Copernicus University in Toruń, Gagarina 13a, 87-100 Toruń, Poland, phone number: +48 511749 195; ORCID ID: http://orcid.org/0000-0002-5021-8871. 


\section{INTRODUCTION}

Financial markets have been growing intensively in the recent years, both in terms of the increase in the value of concluded transactions and the occurrence of new financial instruments. As a result of the transformations, in particular facilitating the access to the markets, as well as extending the portfolio of the available instruments, a significant growth in investment opportunities can be observed. It concerns not only investments based on the financial market, but also investments in real property and alternative investments (Pełka \& Mikita, 2009, pp. 15-20).

In the current economic situation, individual investors have an important role in the functioning of financial markets. They not only provide capital in significant amounts, but also improve the trading liquidity on those markets (Kaniel, Saar \& Titman, 2008, pp. 23-24). In addition, the importance of their investments in the social aspect of economy cannot be underestimated (Dziawgo, 2004, p. 10). Thus, despite the dominant position of institutional investors (Fich, Harford \& Tran, 2015, p. 22), the importance of individual investors is an interesting issue, both from the practical and the theoretical point of view.

\section{THE RESEARCH METHODOLOGY AND THE COURSE OF THE RESEARCH PROCESS}

In connection with the validity and significance of the questions outlined above, the subject of this paper is the issue of financial investments made by individual investors in Poland.

The major goal of this paper is to analyse the investments of individual investors in Poland in terms of their subject. In this regard, the following methods of analysis have been assumed: descriptive, comparative, review of subject literature, analysis of third party research results and analysis of selected results of the individual survey.

The essential part of this study shall be the presentation and description of the selected results of a survey conducted by the author in a group of individual investors in Poland. 


\section{INDIVIDUAL INVESTORS AS PARTICIPANTS OF FINANCIAL MARKETS}

The common definition of the financial market refers to all transactions consisted in exchanging (Dziawgo, 2007, p. 12):

a) money for a financial instrument,

b) a financial instrument for money,

c) a financial instrument for a financial instrument.

The dynamic growth of financial markets observed in the recent years is determined by a number of processes concerning the economy and the society. These include (Matysek-Jędrych, 2008, p. 35):

a) financial liberalisation,

b) financial deregulation,

c) international integration,

d) financial globalisation,

e) technological progress.

As a result of the ongoing transformations, the contemporary financial market has become very extensive, both in terms of the volume of transactions and the number of participants, and also in terms of complexity and size of the catalogue of traded financial instruments. There are many various classifications of financial instruments. One of the most commonly used is the distinction of financial instruments based on their specific nature in relation to the structure of the financial market (Dębski, 2007, p. 21). It is presented in diagram 1. A wide selection of available instruments provides investors with better capabilities in creating the investment portfolio that better meets their expectations.

The major participants of the financial market are investors. It is a group of entities controlling surplus capital that may be allocated in order to increase its value. That method of categorisation of investors makes this group a varied community. In this respect, many methods of classification are used (Banaszczak-Soroka, 2016, pp. 13-18). The basic distinction is made between individual (private) investors and institutional (professional) investors.

Individual investors are entities who make investment decisions personally, without the participation professional agents. Moreover, they act on their own account and do not deal with such activity professionally. Despite the fact that the subject literature does not provide a clear explanation of this term, it usually refers to natural persons investing their savings in various assets (Dziawgo, 2004, p. 46). 
[54]

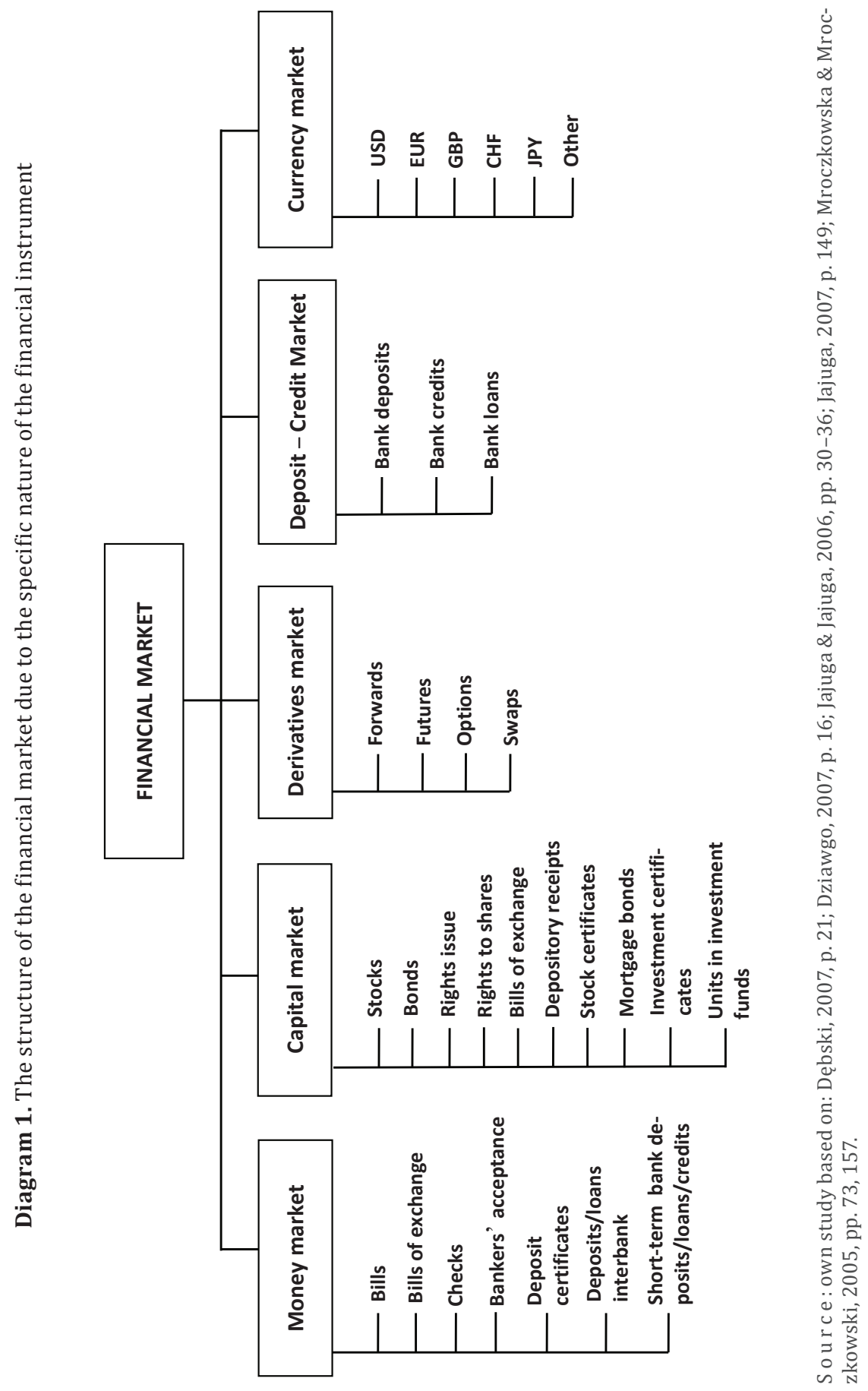


The specific nature of the term "individual investors" causes a great diversification of entities to which it refers. These differences concern, among others, the attitude towards risk, investment goals, wealth, scale of fulfilled undertakings, knowledge and experience, education, market situation assessment capability, assumed time limit of investment. The listed factors influence market behaviour of individual investors, determining the selection of investment strategy and the structure of the investment portfolio (Cichorska, 2015, p. 19).

\section{THE OUTCOME OF THE RESEARCH PROCESS AND CONCLUSIONS}

This part of the paper shall present the analysis of selected results of the thirdparty research as well as the author's survey concerning the examined issue.

\section{INVESTMENTS OF INDIVIDUAL INVESTORS IN POLAND - ANALYSIS OF THIRD-PARTY RESEARCH RESULTS}

The evolution of the financial market, observed in Poland since the 1990s, confirms the significant role that individual investors have in its development. For that reason, in the recent years investment decisions of that group of participants have been the subject of numerous analyses. This part of the paper will explain certain outcomes of third-party research concerning the structure of the investments made by individual investors in Poland.

An interesting and important study encompassing all issues described herein is the annual national study of activity of individual investors in Poland. It is performed by the Individual Investors Association (Stowarzyszenie Inwestorów Indywidualnych, SII). Due to its regular character and the size of the analysed group, it is a valuable analytical and reference material. Diagrams 2, 3 , 4, and 5 present the results of the research obtained in 2010, 2012, 2014 and 2016 respectively. 
Diagram 2. The structure of individual investors' financial investments in Poland in 2010

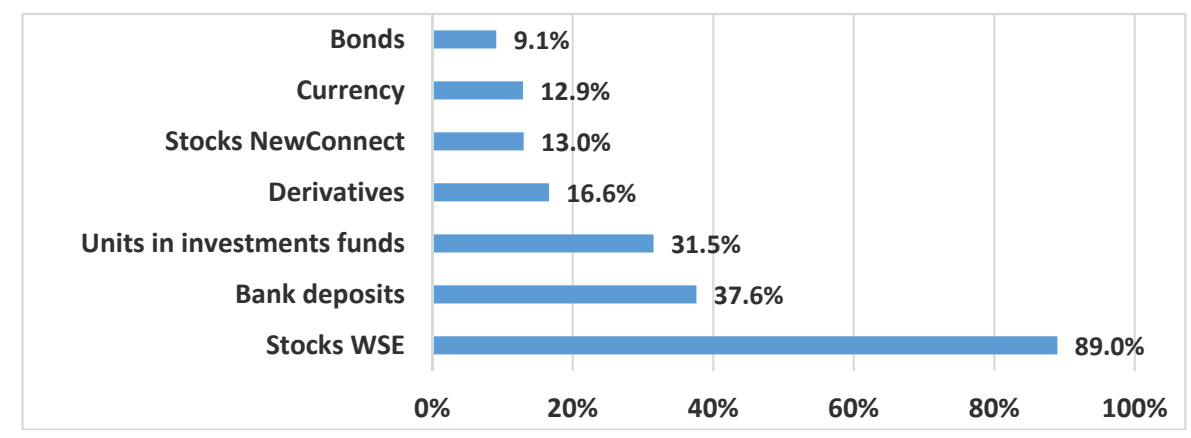

* In the analysed question respondents $(\mathrm{N}=3024)$ could choose more than one answer. S o u r c e : OBI, 2010.

Diagram 3. The structure of individual investors' financial investments in Poland in 2012

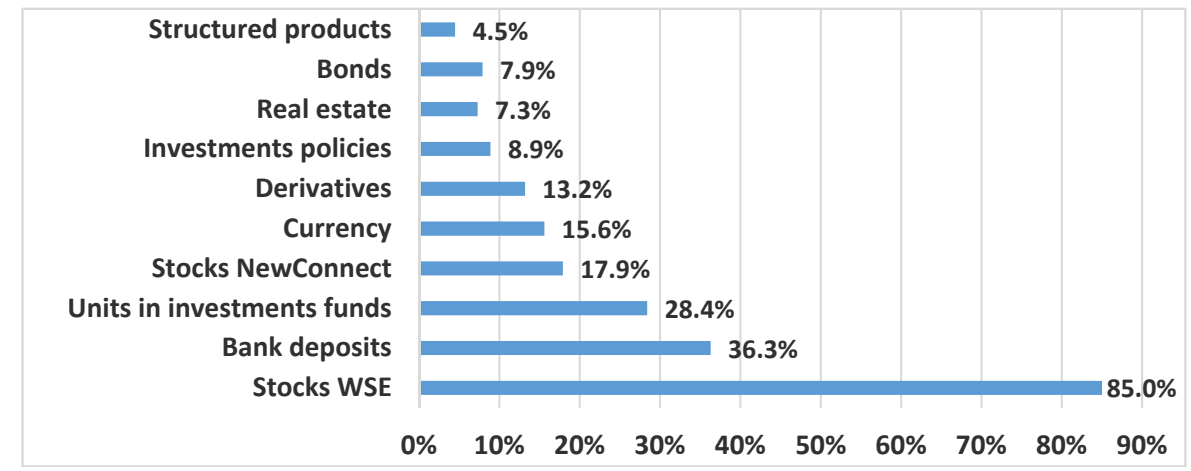

* In the analysed question respondents $(\mathrm{N}=6009)$ could choose more than one answer. S o u r c e: OBI, 2012. 
Diagram 4. The structure of individual investors' financial investments in Poland in 2014

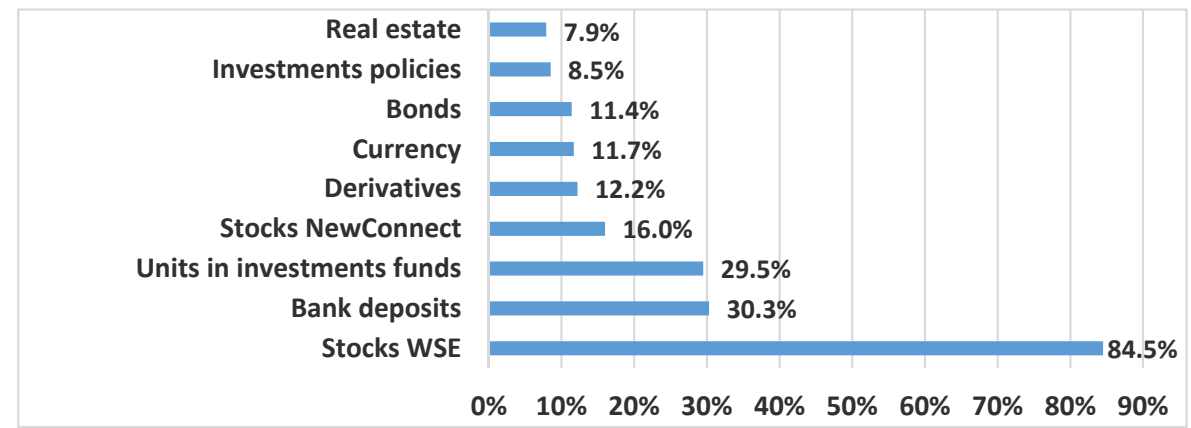

* In the analysed question respondents $(\mathrm{N}=7032)$ could choose more than one answer. S o u r c e : OBI, 2014.

Diagram 5. The structure of individual investors' financial investments in Poland in 2016

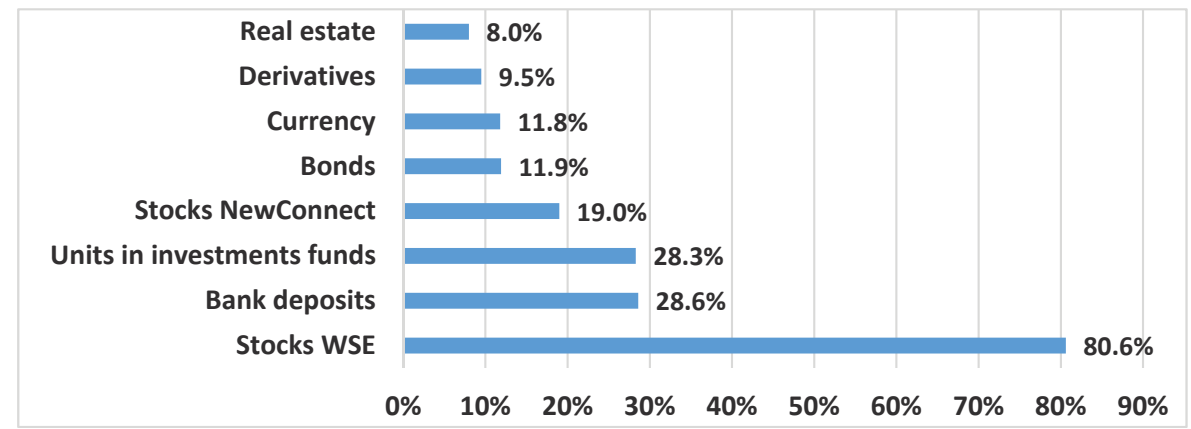

* In the analysed question respondents $(\mathrm{N}=5012)$ could choose more than one answer. S o u r c e : OBI, 2016.

The results of analyses performed by the SII from 2010 to 2016 allow to formulate a number of conclusions concerning the structure of financial investments made by individual investors in Poland during that period.

1. The major subject of investments in the analysed period were stocks. The majority of the respondents declared commitment in this type of investments. 
In 2010, approx. $89.0 \%$ of the surveyed reported investments made in stocks listed on the Warsaw Stock Exchange. In the following years, the interest in that type of shares slightly decreased. In 2016, the percentage of respondents who invested in those stocks was approx. $80.6 \%$.

Additionally, several percent of the surveyed were interested in shares traded on the NewConnect market. They were gaining in popularity during the analysed period.

2. Bank deposits were the next most popular subject of investments in 2010 among individual investors (37.6\%). In the analysed period, their share in the investors' portfolios was gradually decreasing. In 2016 it was only approx. $28.6 \%$. One of the causes of such decrease was considerable reduction of interest rates of that type of instruments.

3. A noticeable increase in individual investors' interest in bonds occurred in the analysed period. In 2010, approx. 9.1\% of the surveyed reported investments in this type of assets. In 2016 this percentage was higher, reaching approx. $11.9 \%$. It can be reasonably concluded that the growth of the stock market of bonds in Poland, and also relatively low interest rates of bank deposits, were the major causes of the observed situation.

4. In the analysed period, individual investors' interest of derivatives decreased significantly. The percentage of respondents who declared using these instruments dropped from $16.6 \%$ in 2010 to $9.5 \%$ in 2016.

5. The percentage of the surveyed investors who participated in investment funds was almost the same during the analysed period. Nearly $30 \%$ of respondents declared involvement in this type of assets.

6. Currencies were the subject of investments of a relatively constant number of respondents in the whole analysed period. The percentage varied from $12 \%$ to $15 \%$.

Research concerning the value and structure of households' financial assets in Poland which is annually performed by Narodowy Bank Polski were used in order to complete the image of an individual investors in Poland. According to NBP classification category of households includes individual farmers, individual entrepreneurs and other natural persons. In this way concept of individual investor is often equated with notion household in literature (Bielawska \& Kordela, 2014, p. 28).

Table 1 and 2 presents detailed data about value and structure of savings of this group of investors in 2010-2016. 
Table 1. The value of households' selected financial assets in Poland in 2010-2016

\begin{tabular}{|c|l|c|c|c|c|}
\hline \hline No. & \multicolumn{1}{|c|}{ Financial assets* } & $\mathbf{2 0 1 0}$ & $\mathbf{2 0 1 2}$ & $\mathbf{2 0 1 4}$ & $\mathbf{2 0 1 6}$ \\
\hline \hline 1 & Bank deposits & 413.1 & 504.2 & 592.4 & 713.9 \\
\hline 2 & Credit union deposits & 13.2 & 15.7 & 12.7 & 10.9 \\
\hline 3 & Units in investment funds & 73.8 & 72.5 & 103.2 & 124.3 \\
\hline 4 & Units in unit-linked insurance funds & 74.1 & 77.9 & 82.7 & 83.5 \\
\hline 5 & Treasury securities & 10.1 & 8.5 & 9.3 & 11.8 \\
\hline 6 & Non-treasury securities & 2.4 & 1.8 & 1.3 & 2.3 \\
\hline 7 & Stocks WSE (includes NC) & 51.1 & 37.2 & 40.5 & 43.6 \\
\hline 8 & & 637.8 & 717.8 & 842.1 & 990.3 \\
\hline \hline
\end{tabular}

* In the analysed issue financial assets not contain cash.

S o u r c e : Rozwój systemu finansowego w Polsce w 2016 r., raport NBP, p. 26; Rozwój systemu finansowego $w$ Polsce w 2013 r, raport NBP, p. 36.

Table 2. The structure of households' selected financial assets in Poland in 2010-2016

\begin{tabular}{|c|l|c|c|c|c|}
\hline \hline No. & \multicolumn{1}{|c|}{ Financial assets* } & $\mathbf{2 0 1 0}$ & $\mathbf{2 0 1 2}$ & $\mathbf{2 0 1 4}$ & $\mathbf{2 0 1 6}$ \\
\hline \hline 1 & Bank deposits & $64.8 \%$ & $70.2 \%$ & $70.3 \%$ & $72.1 \%$ \\
\hline 2 & Credit union deposits & $2.1 \%$ & $2.2 \%$ & $1.5 \%$ & $1.1 \%$ \\
\hline 3 & Units in investment funds & $11.6 \%$ & $10.1 \%$ & $12.3 \%$ & $12.6 \%$ \\
\hline 4 & Units in unit-linked insurance funds & $11.6 \%$ & $10.9 \%$ & $9.8 \%$ & $8.4 \%$ \\
\hline 5 & Treasury securities & $1.6 \%$ & $1.2 \%$ & $1.1 \%$ & $1.2 \%$ \\
\hline 6 & Non-treasury securities & $0.4 \%$ & $0.3 \%$ & $0.2 \%$ & $0.2 \%$ \\
\hline 7 & Stocks WSE (includes NC) & $8.0 \%$ & $5.2 \%$ & $4.8 \%$ & $4.4 \%$ \\
\hline 8 & & $100.0 \%$ & $100.0 \%$ & $100.0 \%$ & $100.0 \%$ \\
\hline \hline
\end{tabular}

* In the analysed issue financial assets not contain cash.

S o u r c e : Rozwój systemu finansowego w Polsce w 2016 r., NBP, p. 26; Rozwój systemu finansowego w Polsce $w 2013$ r, NBP, p. 36. 
The results research conducted by the NBP in 2010 - 2016 allow to formulate a number of conclusions concerning the structure of financial assets of households in Poland in that period.

1. The major subject of savings in the analysed period were bank deposits. In 2010, bank deposits made up about $64.8 \%$ of total value of households' financial assets (without cash) in Poland. In the following years, the interest in that type of financial instruments increased. In 2016, it was approx. $72.1 \%$.

2. Units in investment funds were the next most popular subject of investments in 2010 among households (11.6\%). In the analysed time, their share in the investors' portfolios slightly increased. In 2016 it was approx. $12.6 \%$.

3. In 2010 value of units in unit-linked insurance funds was similar to worth of units in investment funds. Their share was $12.6 \%$ then. In the following years it decreased and was equal 8.4\% in 2016.

4. Moreover, stocks listed on WSE (includes NewConnect) were the significant type of financial assets of households in Poland in the analysed period. In 2010 their share in the total value of them amounted about $8.0 \%$. In the following years, the interest in that type of financial instruments decreased. In 2016, it was equal approx. 4.4\%.

\section{INVESTMENTS OF INDIVIDUAL INVESTORS IN POLAND - ANALYSIS OF AUTHOR'S RESEARCH RESULTS}

For the purposes of this study, the outcomes of the individual survey conducted in the group of individual investors in Poland in 2015 have also been used. It was performed at the author's request by the Individual Investors Association (SII) among the group of 408 individual investors in Poland. The research tool used for the purposes of the survey was an on-line questionnaire published on the SII website. The surveyed group was targeted.

The analysis of the surveyed group of individual investors started with determining their gender. The obtained results are presented in diagram 6 . 
Diagram 6. Division of the surveyed group of individual investors in terms of gender (\%)

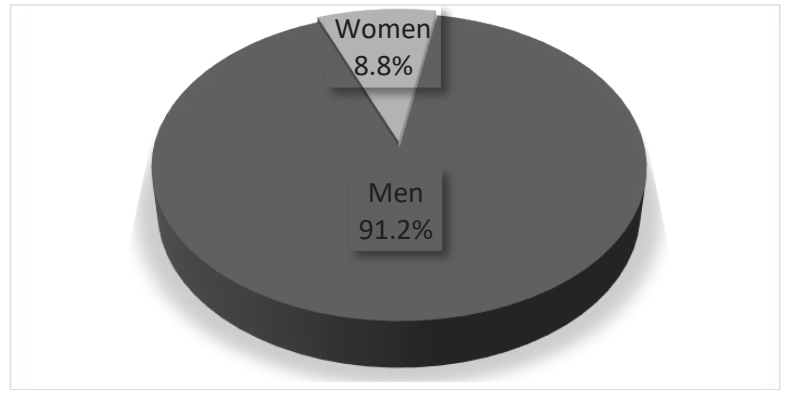

S o u r c e : individual study.

The majority of the surveyed were men (91.2\%). Women were a relatively small group of respondents (8.8\%). Thus, the prevalence of men in the surveyed group is apparent.

Considering the age of the respondents in the surveyed group, there is a noticeable diversification. In this regard, the following age categories have been distinguished:
a) under 30,
b) at least 30 , but less than 40 ,
c) at least 40 , but less than 50 ,
d) over 50 .

The obtained results are presented in diagram 7 .

Diagram 7. Division of the surveyed group of individual investors in terms of age (\%)

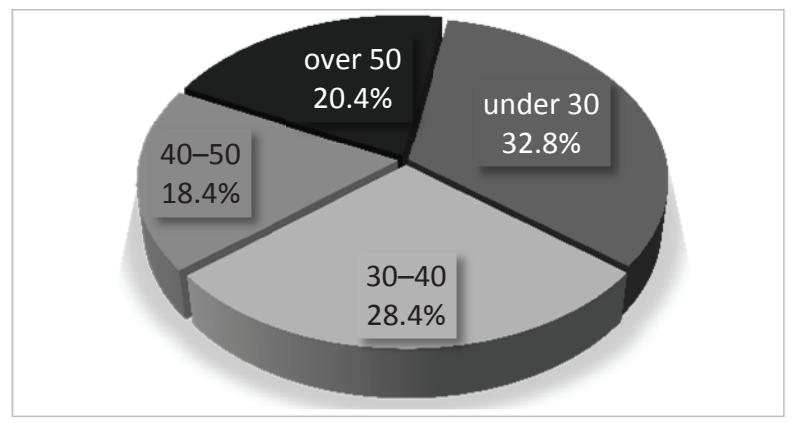

S o u r c e : individual study. 
The largest group were the youngest investors, under 30 years of age. Their portion in the analysed group was approx. 32.8\%. The second largest age group, reaching approx. 28.4\%, were respondents from 30 to 40. Persons over 50 and aged 40 to 50 were the smallest groups, with the percentage of $20.4 \%$ and $18.4 \%$, respectively.

The analysed group of individual investors is also diversified in terms of investment experience. The review of the subject literature allows to assume that the experience of beginning investors does not exceed 3 years. However, persons with at least 10 years of experience in investing have considerable knowledge and skills (Dziawgo, 2016, pp. 108-109). Based on these guidelines, the analysed group has been divided into three categories presented in diagram 8 .

Diagram 8. Division of the surveyed group of individual investors in terms of investment experience (\%)

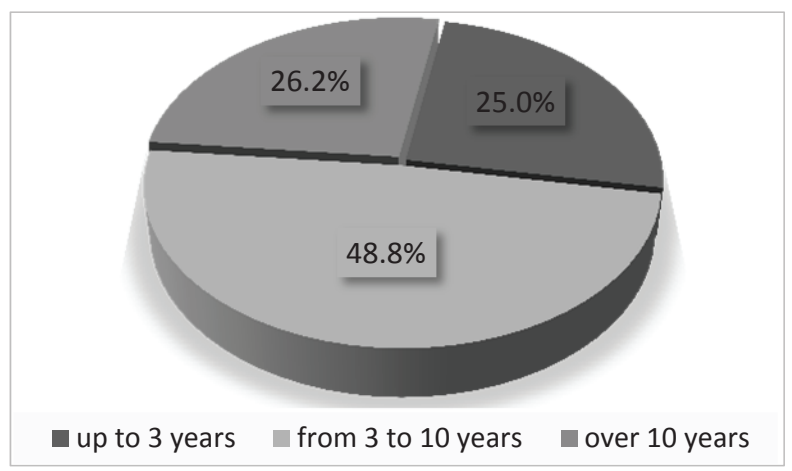

S o u r c e : individual study.

The largest group among the surveyed individual investors had from 3 to 10 years of experience in investing. The percentage of this group reached approx. 48.8. The portion of respondents with experience exceeding 10 years nearly reached $26.2 \%$. The investors with the smallest experience, not exceeding 3 years, were approx. $25 \%$ of the entire group.

The data concerning the subjects of investments made by individual investors are presented in diagram 9. 
Diagram 9. Subjects of investments made by individual investors results of individual research

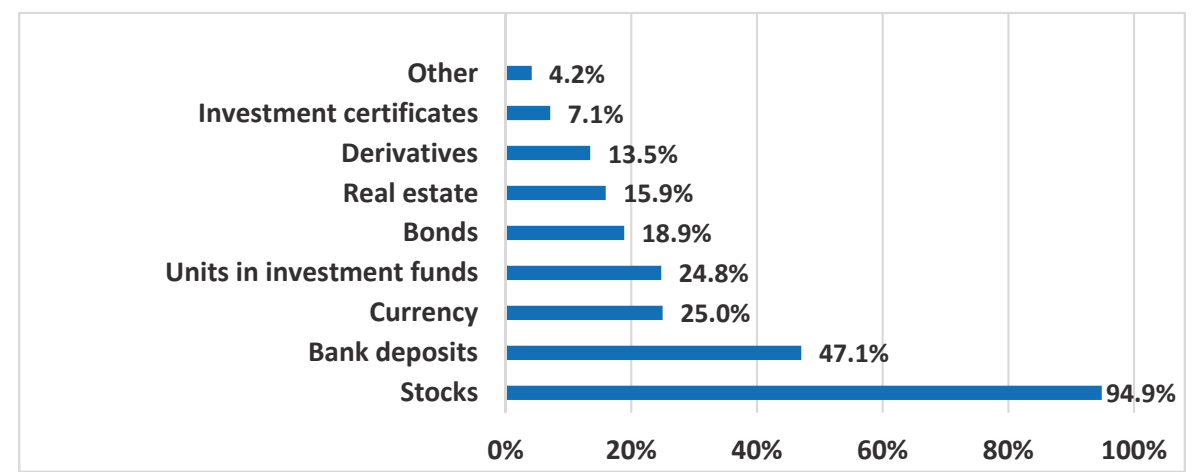

* In the analysed question respondents $(\mathrm{N}=408)$ could choose more than one answer. The total amount of indications in the analysed field was 953.

S o u r c e : individual study.

The major subjects of investments in the surveyed group of investors were stocks and shares (94.4\%). It implies that most investors in the analysed group were active on the stock market. The other most popular subjects were: bank deposits (47.1\%), currencies (25.0\%), units in investment funds $(24.8 \%)$ and bonds (18.9\%). Part of the surveyed (4.2\%) indicated different means of funds allocation, other than the ones specified in the survey question, including gold, silver, coins, social lending, savings accounts.

The further analysis concerned the investments made by the surveyed investors in comparison with their investment experience. Relevant data are presented in diagram 10.

The obtained results indicate that investors having the greatest investment experience, i.e. exceeding 10 years, were more active in the field of investments. Their investment portfolios, encompassing a greater variety of financial instruments, were more diversified. The causes of this situation include relatively larger value of capital held by the investors. This could be confirmed by a relatively large scale of involvement on the real estate market. Additionally, greater experience of investors is reflected in increased tendency to take risks, which might be linked to the relatively higher usage of derivatives. 
Diagram 10. Subjects of investments made by individual investors compared with their investment experience - results of individual research

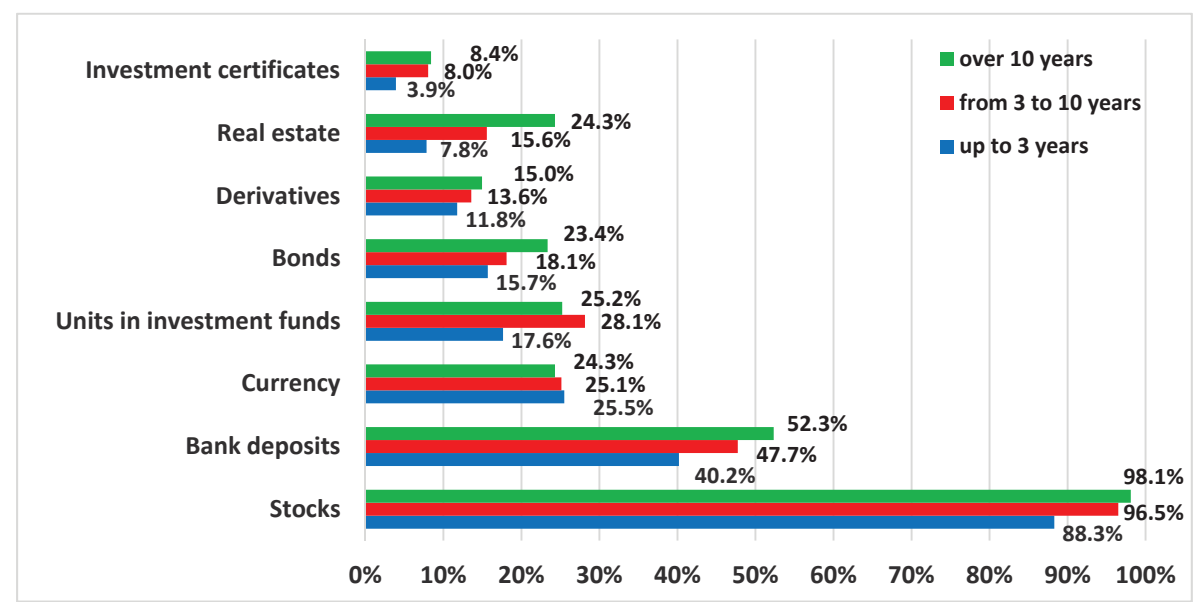

* In the analysed question respondents $(\mathrm{N}=408)$ could choose more than one answer. The total amount of indications in the analysed field was 953.

S o u r c e : individual study.

\section{ConCLUSIONS}

The establishment and growth of the Warsaw Stock Exchange (GPW), as well as the related NewConnect market and Catalyst bond market, significantly extended the investment offer available to investors in Poland. The extensive portfolio of available financial instruments generates better possibilities to adjust the investment strategy to the expectations of individual investors. Nevertheless, bank deposits have remained the main financial assets of households in Poland in analysed time. However, active individual investors often invested their funds in other financial instruments.

Considering the analysis of the subjects of investments made by this particular group of private investors, it can be noticed that stocks were the substantial asset of investments made in the recent years. The study conducted by the SII indicated a gradual decrease in the number of investments in stocks listed on the main market of the Warsaw Stock Exchange. At the same time, the interest in stocks traded on the NewConnect market increased. The outcomes of the individual research have confirmed that stocks were the major subject of investments of individual investors. 
Bank deposits were the second most popular subject of investments among the surveyed investors according to OBI and author's research. However, the interest in these assets among the participants of the survey gradually decreased in the analysed period.

An interesting observation was the growing popularity of bonds among individual investors. Despite the cases of bankruptcy of bonds issuers in Poland, it has been noticed that the percentage of persons investing in this type of financial instruments increased. Relatively higher bonds interest rates in comparison with bank deposits caused that these instruments constitute an attractive alternative of bank deposits in current market conditions.

Comparing the results of the research conducted by the author with the outcomes obtained by the SII, considerable similarities can be noticed. Relatively more individual investors participating in the author's research invested in certain financial instruments, among others derivatives and currencies. It might be concluded that the observed differences are related with the specific character of the surveyed group. Targeted selection of the analysed group and the issues covered by the author's study could have encouraged investors who were more active on the financial market to participate in the survey.

\section{REFERENCES}

Banaszczak-Soroka, U. (2016). Inwestor na rynku papierów wartościowych. (Investor on the securities market.) In U. Banaszczak-Soroka (Ed.). Rynek papierów wartościowych. Inwestorzy, instrumenty finansowe i metody ich wyceny. (Securities market. Investors, financial instruments and valuation methods.) Warszawa: Wydawnictwo C.H. Beck.

Bielawska, A., \& Kordela, D. (2014). Kierunki lokowania nadwyżek finansowych przez inwestorów indywidualnych w Polsce w latach 2008-2012. (Directions of financial surplus investments made by private investors in Poland in the years 2008-2012.) Annales Universitatis Mariae Curie-Skłodowska, sectio H - Oeconomia, 48(3), 27-35.

Cichorska, J. (2015). Inwestor Indywidualny. Mechanizmy podejmowania decyzji inwestycyjnych. (Individual Investor. Ways of making investment decisions.) In J. Cichorska (Ed.). Zarzqdzanie portfelem inwestycyjnym. Inwestor indywidualny na rynku finansowym. (Portfolio management. Individual investor on the financial market.) Katowice: Wydawnictwo Uniwersytetu Ekonomicznego w Katowicach.

Dębski, W. (2007). Rynek finansowy i jego mechanizmy. Podstawy teorii i praktyki. (The financial market and its mechanisms. Basics of theory and practice.) Warszawa: Wydawnictwo Naukowe PWN.

Dziawgo, D. (2004). Stowarzyszenia indywidualnych inwestorów i kluby inwestycyjne na rynku papierów wartościowych. (Associations of individual investors and invest- 
ment clubs on the securities market.) Toruń: Wydawnictwo Uniwersytetu Mikołaja Kopernika.

Dziawgo, D. (2007). Rynek finansowy. Istota - instrumenty - funkcjonowanie. (The financial market. Essence - instruments - functioning.) Warszawa: Wydawnictwo Stowarzyszenia Księgowych w Polsce.

Dziawgo, D. (2016). Znaczenie raportowania pozafinansowego $\mathrm{w}$ opinii indywidualnych inwestorów. (Non-financial reporting importance from individual investors' perspective.) Prace Naukowe Uniwersytetu Ekonomicznego we Wrocławiu, 436, 105-114. http://dx.doi.org/10.15611/pn.2016.436.11.

Fich, E.M., Harford, J., \& Tran, A.L. (2015). Motivated monitors: The importance of institutional investors' portfolio weights. Journal of Financial Economics, 118(1), 21-48. http://dx.doi.org/10.1016/j.jfineco.2015.06.014.

Jajuga, K., \& Jajuga, T. (2006). Inwestycje. (Investments.) Warszawa: Wydawnictwo Naukowe PWN.

Jajuga, K. (2007). Elementy nauki o finansach. (Elements of finance science.) Warszawa: PWE.

Kaniel, R., Saar, G., \& Titman, S. (2008). Individual Investor Trading and Stock Returns. The Journal of Finance, 63(1), 273-310. http://dx.doi.org/10.1111/j.15406261.2008.01316.x.

Matysek-Jędrych, A. (2008). Współczesne przeobrażenia systemu finansowego i ich konsekwencje. (The Contemporary Transformation of the Financial System and its Consequences.) Bank i Kredyt, 1, 34-60.

Mikita, M., \& Pełka, W. (2009). Rynki inwestycji alternatywnych. (Alternative investment markets.) Warszawa: Poltext.

Mroczkowska, R., \& Mroczkowski, R. (2005). Weksel w praktyce. (Bill in practice.) Gdańsk: Wydawnictwo ODDK.

Ogólnopolskie Badanie Inwestorów - OBI 2010, (Nationwide Investor Research 2010) http://www.sii.org.pl/3124/edukacja-i-analizy/badania-i-rankingi/ogolnopolskiebadanie-inwestorow-obi-2010.html (accessed: 20.01.2018).

Ogólnopolskie Badanie Inwestorów - OBI 2012, (Nationwide Investor Research 2012)

http://www.sii.org.pl/4380/edukacja-i-analizy/badania-i-rankingi/ogolnopolskie-badanie-inwestorow-obi-2012.html (accessed: 20.01.2018).

Ogólnopolskie Badanie Inwestorów - OBI 2014, (Nationwide Investor Research 2014)

http://www.sii.org.pl/7586/edukacja-i-analizy/badania-i-rankingi/ogolnopolskie-badanie-inwestorow-obi-2014.html (accessed: 20.01.2018).

Ogólnopolskie Badanie Inwestorów - OBI 2016, (Nationwide Investor Research 2016)

http://www.sii.org.pl/10487/edukacja-i-analizy/badania-i-rankingi/ogolnopolskiebadanie-inwestorow-obi-2016.html (accessed: 20.01.2018).

Rozwój systemu finansowego w Polsce w 2013 r. (The development of financial system in Poland in 2013), NBP.

Rozwój systemu finansowego w Polsce w 2016 r. (The development of financial system in Poland in 2016), NBP. 